\title{
Zircon Xenocrysts from the Shaka Ridge Record Ancient Continental Crust: New U-Pb Geochronological and Oxygen Isotopic Data
}

\author{
Sergey G. Skublov $\circledast^{* 1,2}$, Natalia A. Rumyantseva ${ }^{2,3}$, Qiuli Li $^{4}$, Boris G. Vanshtein ${ }^{3}$, \\ Dmitriy I. Rezvukhin ${ }^{5}$, Xianhua $\mathbf{L i}^{4}$ \\ 1. Institute of Precambrian Geology and Geochronology of Russian Academy of Sciences, St. Petersburg 199034, Russia \\ 2. Saint Petersburg Mining University, St. Petersburg 199106, Russia \\ 3. Institute for Geology and Mineral Resources of the World Ocean (VNIIOkeangeologia), St. Petersburg 190121, Russia \\ 4. State Key Laboratory of Lithospheric Evolution, Institute of Geology and Geophysics, \\ Chinese Academy of Sciences, Beijing 100029, China \\ 5. Sobolev Institute of Geology and Mineralogy, Siberian Branch of the Russian Academy of Sciences, Novosibirsk 630090, Russia \\ (D)Sergey G. Skublov: https://orcid.org/0000-0002-5227-4260
}

\begin{abstract}
Over the past two decades, a significant number of discoveries of ancient zircon xenocrysts in ocean-floor magmatic rocks have been reported. These findings provide compelling evidence for the presence of ancient continental crust within young oceanic lithosphere. Almost all finds of ancient zircon xenocrysts within oceanic crust are from the Mid-Atlantic Ridge. For other localities, however, similar data are very limited. This report presents the first age determinations (U-Pb, SHRIMPII) and isotope-geochemical data (oxygen, trace and rare earth elements) for zircon xenocrysts from gabbro-diorites of the Shaka Ridge, in the vicinity of the Shaka fracture zone, near the western end of the Southwest Indian Ridge. The work is based on a study of bottom rock material dredged during expeditionary research on the R/V “Akademik Fedorov" (Russia) in 2016. The U-Pb isotope system of the zircon xenocrysts recorded a crystallization age of $\sim 2.8 \mathrm{Ga}$ at an upper discordia intercept and an age of $\sim 600 \mathrm{Ma}$ interpreted as the timing of a superimposed thermal event at a lower discordia intercept. The zircon xenocrysts show geochemical signatures of magmatic origin, i.e., fractionated REE distribution spectra with an increase in chondrite-normalized values from light to heavy REE, positive Ce anomalies and negative Eu anomalies, and high $\mathrm{Th} / \mathrm{U}$ ratios (0.59-7.77). In discrimination diagrams based on a series of inter-element relationships, zircon compositions fall into the fields of zircons from rocks of continental crust, mostly granitoids. The Li content of the zircons is high (1.8 ppm-50 ppm), adding further evidence to their derivation from rocks of continental crust. During their residence within young oceanic crust, the zircon xenocrysts experienced alterations under the influence of submarine high-temperature hydrothermal fluids, which selectively affected the distribution of trace elements in the zircons and reduced the $\delta^{18} \mathrm{O}$ values to $1.75 \%-3.15 \%$. The presence of obviously older zircons in Shaka gabbro-diorites clearly demonstrates the presence of ancient continental fragments and their recycling into the mantle at the western end of the Southwest Indian Ridge.

KEY WORDS: zircon, U-Pb geochronology, oxygen isotopes, trace elements, rare earth elements, Shaka Ridge, South Atlantic, Southwest Indian Ridge.
\end{abstract}

\section{INTRODUCTION}

The finding of ancient zircons (Paleozoic to Proterozoic) in oceanic gabbros from the Mid-Atlantic Ridge near the Kane fracture zone (Pilot et al., 1998) triggered extensive discussion that is still under way. The primary issue is the mechanism of

*Corresponding author: skublov@yandex.ru

(C) The Authors 2022. This article is published with open access at Springerlink.com

Manuscript received Novenber 24, 2020.

Manuscript accepted January 17, 2021. incorporation of these zircons into young oceanic crust. Initially, attempts were made to explain the presence of obviously older zircons either by contamination during sampling of rocks or separation of minerals. However, a significant number of such discoveries (about twenty publications, links below), and a wide range of laboratories in which sample preparation was performed, suggest that this phenomenon is not uncommon, and zircons should be considered as true xenocrysts (Bea et al., 2020). The results of these studies provide convincing evidence for the presence of ancient continental crust in young oceanic lithosphere (e.g., Bortnikov et al., 2019; Ashwal et al., 2017; Kamenetsky et al., 2001).

Skublov, S. G., Rumyantseva, N. A., Li, Q. L., et al., 2022. Zircon Xenocrysts from the Shaka Ridge Record Ancient Continental Crust: New U-Pb Geochronological and Oxygen Isotopic Data. Journal of Earth Science, 33(1): 5-16. https://doi.org/10.1007/ s12583-021-1422-2. http://en.earth-science.net 
Zircon is a unique indicator and a common representative of ancient continental lithosphere. It retains isotope-geochemical signatures and records information on the reworking of ancient crust during various geodynamic processes (Leontev et al., 2020; Zhao et al., 2019; Xu and Zhang, 2018). Almost all finds of ancient zircons within oceanic crust come from the Mid-Atlantic Ridge (Bea et al., 2020; Bortnikov et al., 2019, 2008; Shulyatin et al., 2019; Kostitsyn et al., 2018, 2015, 2009; Kremenetskiy et al., 2018; Aranovich et al., 2013; Skolotnev et al., 2010; Sharkov et al., 2004; Pilot et al., 1998; Belyatskii et al., 1997). This is probably due to the fact that this area of the world ocean has been systematically studied for several decades. For the Indian Ocean, however, the available data are scarce (Ashwal et al., 2017; Cheng et al., 2016; Torsvik et al., 2013). In this contribution we report the first age determinations and isotope-geochemical data for zircons from the Shaka Ridge, adjacent to the Shaka fracture zone, near the western end of the Southwest Indian Ridge. We provide evidence for the continental derivation of the zircons and discuss possible mechanisms of their transportation into young oceanic crust.

\section{GEOLOGICAL BACKGROUND AND SAMPLING}

The Southwest Indian Ridge (SWIR) is a Meso-Cenozoic ocean floor uplift. Its formation began as a result of the Gondwana supercontinent breakup in the Mesozoic (Norton and Sclater, 1979). The ridge extends $\sim 8000 \mathrm{~km}$ from the Bouvet triple junction in the South Atlantic to the Rodrigues triple junction in the southern Indian Ocean. The SWIR is an ultraslow spreading ridge with spreading rates of only $14-18 \mathrm{~mm} /$ yr. Bouvet Island, a hotspot, is located $\sim 300 \mathrm{~km}$ east of the Bouvet triple junction and $55 \mathrm{~km}$ south from the nearest SWIR segment (Lin et al., 2003; Georgen et al., 2001). Within the SWIR, there is an intensely dissected topography with elevation differences of up to $4 \mathrm{~km}$ or more as well as a significant number of transform faults having their own names. One of such transform faults is the Shaka fault. The namesake Shaka Ridge is located on the northeastern flank of the latter; it is an underwater upland extending to the east. The Shaka Ridge is thus not a part of the SWIR, but is located in its immediate vicinity (Fig. 1).

Currently, there is a lack of reliable information about the origin and formation of the Shaka Ridge (Rumyantseva et al., 2021). The first detailed geological and geophysical study of the Shaka Ridge area was carried out by the staff of the Woods Hole Oceanographic Institution (WHOI) during December and January, 2001. This research was part of the geophysical mapping and dredging program of the southwestern part of the Indian Ridge between $\mathrm{E}^{\circ}$ and $\mathrm{E} 16^{\circ}$ (Lin et al., 2003, 2001). As a result of these studies, pronounced mantle heterogeneity of the area was established, which is expressed in differing indicators of the gravitational field. The largest negative mantle anomaly $(-50 \mathrm{mGal})$ was recorded in the area of a number of relict volcanic cones at the junction of the Shaka fault and the Shaka Ridge $\left(\mathrm{S} 52.25^{\circ} ; \mathrm{E} 10.5^{\circ}\right)$. Dredging of the cones showed that they were composed of alternating layers of ash and lapilli tuff. This evidence confirmed the researchers' assumption that the Bouvet hotspot interacted with this area at $\sim 20 \mathrm{Ma}$ (Lin et al., 2001). The magnetic age of Shaka Ridge rocks is between 35$53 \mathrm{Ma}$ (Sauter and Cannat, 2010; Fisher and Sclater, 1983).

Our work is based on a study of bottom rock material dredged during expeditionary research within the Shaka Ridge on the R/V "Akademik Fedorov" (Russia) in the spring of 2016. The research was performed in two stages. At the first stage, a bathymetric survey of seabed topography using a multibeam echo sounder was carried out. Based on the results, a geomorphological map was prepared, and locations for dredging stations were selected. In geomorphological terms, the study area has a substantial topographic relief with a major northeaststriking fault and individual volcanic edifices. At the second stage, $\sim 696 \mathrm{~kg}$ of bottom rock materials were sampled at the selected locations using a bottom dredge sampler. The dredged material represents rock fragments of different composition, from sedimentary siltstones to basaltoids. All these samples are weakly rounded or angular with some being covered by Fe-Mn

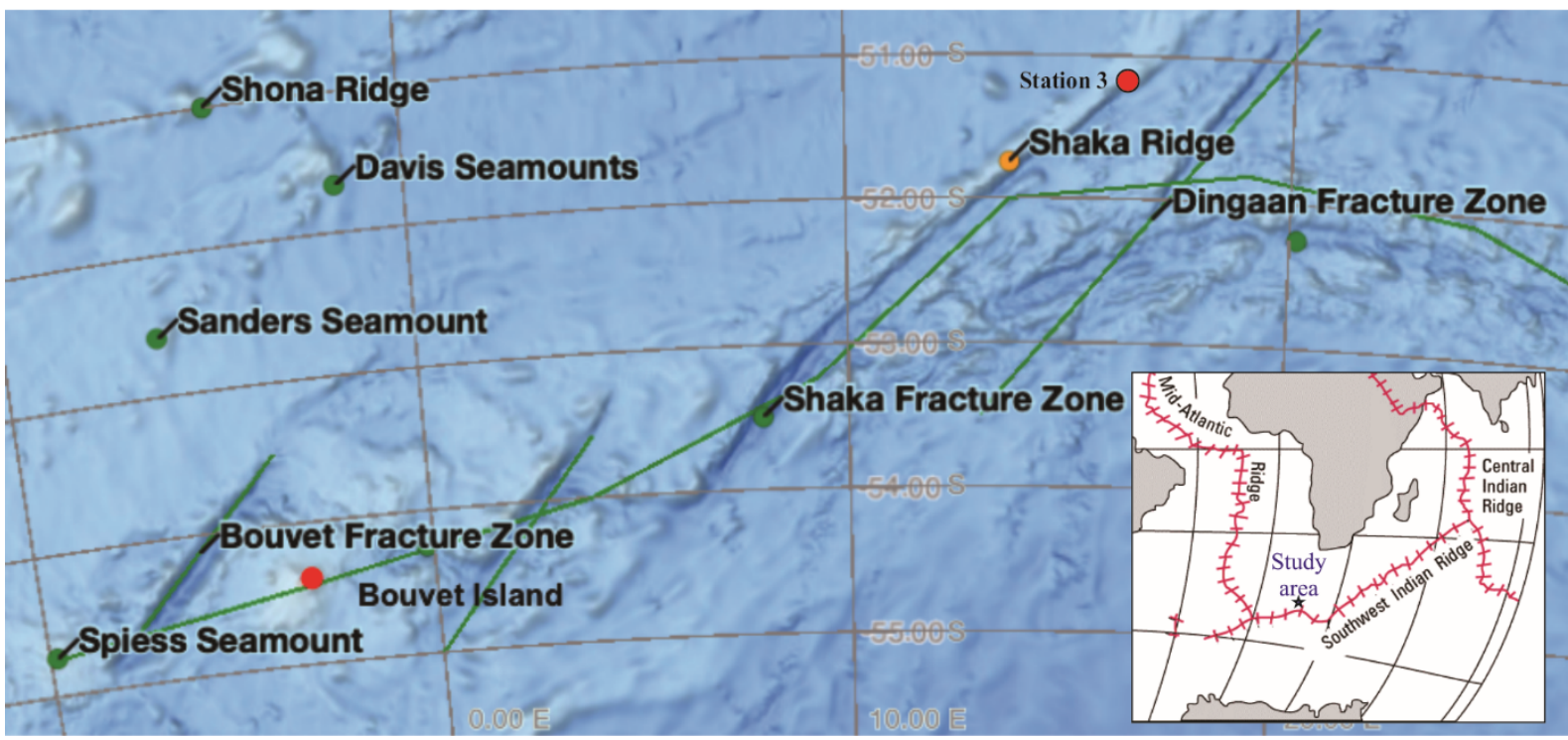

Figure 1. Map of the Shaka Ridge area. Information from open sources (https://www.ngdc.noaa.gov/gazetteer/) was used as a topographic basis. "Station 3” denotes sampling location. Inset shows the geographical position of the study area. 
crusts. After lifting the dredge aboard the vessel, the bottom rock materials waere extracted from the dredge and sorted according to rock types for further geological description, photographing and weighing. Among the bottom rock materials sampled from dredging station FB-2016-3-2 on the northeastern flank of the middle part of the Shaka Ridge (S51.057 $8^{\circ}$; E13.164 $9^{\circ}$ ), gabbro, diorite, dolerite, basaltic andesite, trachybasalt and gabbro-diorite are the predominant lithologies. A representative sample of gabbro-diorite from this station (FB2016-3-2-55) was taken for a further analytical study.

\section{ANALYTICAL METHODS}

Zircon grains were recovered from the gabbro-diorite (sample FB-2016-3-2-55) by conventional magnetic and heavy liquid techniques. Once separated, the zircon grains were mounted in epoxy together with the TEMORA-2 (Black et al., 2004) and 91500 (Wiedenbeck et al., 1995) zircon standards. Spots for in-situ analyses were selected by using both transmittedand reflected-light images in order to avoid cracks and inclusions. Cathodoluminescence (CL) and back-scattered electron (BSE) images were obtained at the Centre for Isotopic Research of the All-Russian Geological Research Institute (St. Petersburg) using a CamScan MX2500S scanning electron microscope (SEM) coupled with a QLI/QUA2 CL and operated at 12 $\mathrm{kV}, 5-7 \mathrm{nA}$ and a working distance of 31-33 mm.

The U-Pb dating of zircons was performed on a SHRIMPII ion microprobe at the Centre of Isotopic Research of the AllRussian Geological Research Institute. The U-Pb measurements were carried out by the technique described in Bröcker et al. (2014), Rodionov et al. (2012) and Williams (1998). The intensity of primary $\mathrm{O}_{2}$ beam was $4 \mathrm{nA}$, and the spot (crater) was $20 \mu \mathrm{m}$ across. The obtained data were processed using the SQUID program (Ludwig, 2001). The U/Pb ratios were normalized to the value of the TEMORA zircon standard, 0.0668 , corresponding to an age of $416.75 \mathrm{Ma}$ (Black et al., 2004). The errors of single analyses $(\mathrm{U} / \mathrm{Pb}$ ratios and ages) were at the $\pm 1 \sigma$ level, and the errors of calculated concordant ages and intercepts with concordia were at the $2 \sigma$ level. Error in standard calibration was $0.36 \%$. The concordia plots were constructed using the ISOPLOT/EX program (Ludwig, 2003).

Oxygen isotope compositions of zircon were determined at the Institute of Geology and Geophysics of the Chinese Academy of Sciences (Beijing) on a Cameca IMS-1280 ion microprobe. Analytical procedures are similar to those described in Tang et al. (2015) and $\mathrm{Li}$ et al. (2010). The $\mathrm{Cs}^{+}$primary beam was accelerated at $10 \mathrm{kV}$ with an intensity of ca. $2 \mathrm{nA}$. The spot size was about $20 \mu \mathrm{m}$ in diameter $(10 \mu \mathrm{m}$ beam diameter $+10 \mu \mathrm{m}$ raster). The measured ${ }^{18} \mathrm{O} /{ }^{16} \mathrm{O}$ ratios were normalized to the standard VSMOW $\left({ }^{18} \mathrm{O} /{ }^{16} \mathrm{O}=0.0020052\right)$. We performed oxygen isotope measurements at spots located directly adjacent to pits after $\mathrm{U}-\mathrm{Pb}$ isotope analyses. Before measuring, the sample was re-polished to remove the pits from previous analyses. The instrumental mass fractionation (IMF) was corrected using the TEMORA-2 zircon standard. The second reference zircon 91500 was analyzed as an unknown to ascertain the veracity of the IMF. Four measurements of the 91500 zircon during the course of the present study yielded an average ${ }^{18} \mathrm{O}$ value of $10.07 \%$ o $\pm 0.08 \%$ ( $\left.2 \mathrm{SD}\right)$. It is in agreement with the value of $9.9 \%$ for the 91500 zircon standard (Wiedenbeck et al., 2004).

Measurements of zircon trace element composition were performed using a Cameca IMS-4f ion microprobe at the Yaroslavl' Branch of the Institute of Physics and Technology of the Russian Academy of Sciences. We mainly followed the analytical procedure described in Dokukina et al. (2014), Fedotova et al. (2008) and Hinton and Upton (1991). The primary $\mathrm{O}^{2-}$ ion beam spot size was $\sim 20 \mu \mathrm{m}$. Each analysis was averaged from 3 measurement cycles. Concentrations of trace elements were calculated from the normalized to ${ }^{30} \mathrm{Si}^{+}$secondary ion intensities using calibration curves based on a set of reference glasses (Jochum et al., 2006, 2000). NIST-610 reference glass (Rocholl et al., 1997) was used as a daily monitor for trace element analyses. Accuracy of trace element measurements was up to $10 \%$ and $20 \%$ for concentrations of more than $1 \mathrm{ppm}$ and between $0.1 \mathrm{ppm}$ and $1 \mathrm{ppm}$, respectively. To construct REE distribution spectra, the composition of zircon was normalized to that of chondrite CI (McDonough and Sun, 1995). The zircon crystallization temperature was determined by the Ti-in-Zrn thermometer (Watson et al., 2006).

\section{RESULTS}

\subsection{Petrogeochemical Features of the Host Rock}

On macroscopic examination, sample F-B-2016-3-2-55 is a rounded, slightly angular rock fragment weighing $8.5 \mathrm{~kg}$ and $18 \times 17 \times 13 \mathrm{~cm}^{3}$ in size. It is a coarse-grained crystalline rock with a massive structure. Sample petrography is shown in Fig. 2. Rock-forming minerals are plagioclase $\left(\mathrm{An}_{45-50} ; 55 \% ; 0.6-\right.$ $4.0 \mathrm{~mm}$ in size), hornblende ( $25 \% ; 0.2-1.5 \mathrm{~mm})$, quartz $(10 \%$; $0.4-0.6 \mathrm{~mm})$, K-feldspar ( $5 \%$; $0.2 \mathrm{~mm}$ ), and biotite $(5 \%$; $0.4-$ $1.0 \mathrm{~mm})$. Accessory minerals are zircon, apatite and titanite with epidote and chlorite occurring as secondary minerals. As is evident from its mineralogy and degree of alteration, the rock appears to have undergone greenschist-facies metamorphism. The structure of groundmass is hypidiomorphic granular with poikilitic domains. Plagioclase is saussuritized and crosscut by thin chlorite veins; it is also densely populated by inclusions of apatite, to a lesser extent biotite and hornblende. Hornblende forms irregularly-distributed elongated crystals with inclusions of biotite. Quartz is mostly xenomorphic and fills interstices between plagioclase crystals and colored minerals, although irregular-shaped individual grains are recognized as well. Biotite is present as individual laths, intergrowths and inclusions in principle rock-forming minerals. Zircon appears as irregular-shaped grains or prismatic crystals showing square cross-sections.

According to the TAS classification diagram (Middlemost, 1994), the studied rock falls into the field of gabbro-diorites of normal alkalinity $\left(\mathrm{Na}_{2} \mathrm{O}+\mathrm{K}_{2} \mathrm{O}=3.62 \mathrm{wt} . \%\right)$ with sodium being predominant over potassium $\left(\mathrm{Na}_{2} \mathrm{O} / \mathrm{K}_{2} \mathrm{O}=2.26\right)$. The bulk sample is characterized by a high $\mathrm{Al}_{2} \mathrm{O}_{3}$ content (22.65 wt.\%), whereas $\mathrm{MgO}$ (2.37 wt.\%), $\mathrm{CaO}\left(10.84\right.$ wt.\%) and total $\mathrm{Fe}_{2} \mathrm{O}_{3}$ (5.22 wt.\%) abundances are relatively low. The concentrations of $\mathrm{MnO}, \mathrm{TiO}_{2}$ and $\mathrm{P}_{2} \mathrm{O}_{5}$ are 0.10 wt. $\%, 0.62$ wt.\% and 0.13 wt. $\%$, respectively. The bulk rock demonstrates high concentrations of large ion lithophile elements (LILE; $\mathrm{Rb}=49 \mathrm{ppm}$, $\mathrm{Ba}=143 \mathrm{ppm}, \mathrm{Pb}=15 \mathrm{ppm}$ ), yet relatively low levels of high 


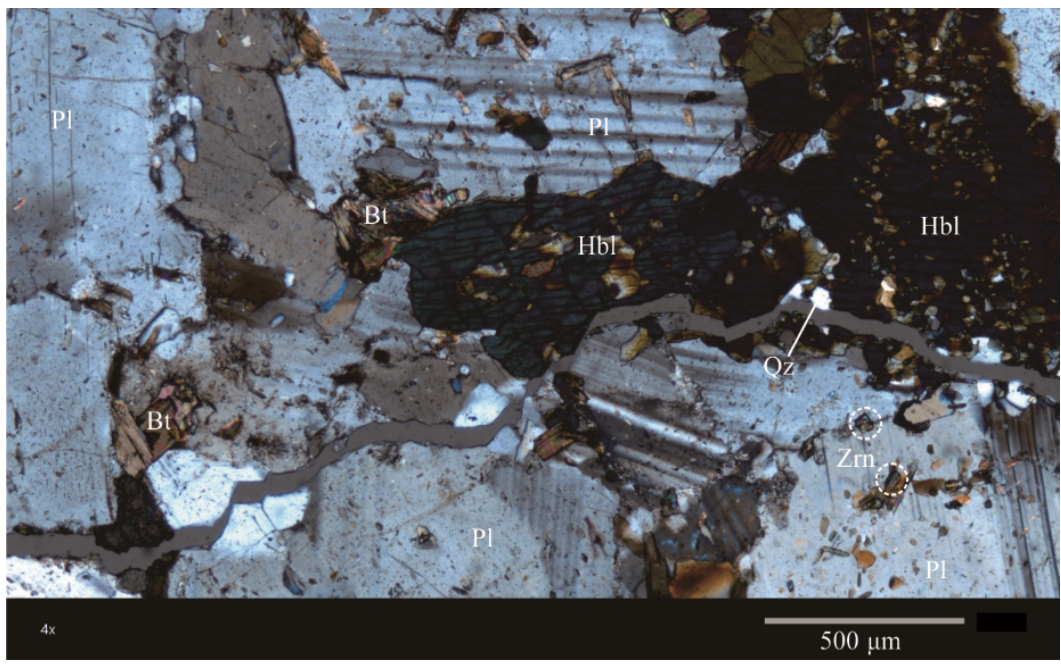

Figure 2. Microphotograph showing a representative texture of sample F-B-2016-3-2-55. Crossed-polarized light. Bt. Biotite, Hbl. hornblende; Pl. plagioclase; Qz. quartz; Ttn. titanite; Zrn. zircon.

field strength elements (HFSE; $\mathrm{Nb}=6.9 \mathrm{ppm}, \mathrm{Ta}=0.33 \mathrm{ppm}$ ). The distribution of rare earth elements (REE), normalized to chondrite $\mathrm{C} 1$, shows a gradual decrease from light to heavy $\mathrm{REE}$ with a negative Eu anomaly $\left(\mathrm{Eu} / \mathrm{Eu}^{*}=0.80\right)$. The bulkrock geochemistry data is reported in Table S1.

\subsection{Zircon Characterization}

The zircon grains separated from the gabbro-diorite are elongated (with aspect ratios $1: 2-1: 3$ ) or isometric with pitted and corroded surfaces (Fig. 3). The grain size generally does not exceed 150-200 $\mu \mathrm{m}$. In CL imaging, the zircon population is generally dark with shades from almost black to dark gray. Occasionally, individual domains bright in CL are recognized in both the interior and rim parts of the grains (e.g., grain
6.1, Fig. 3). Some examples show sector-zoned CL responses (e.g., grain 3.1, Fig. 3), where domains with different internal textures randomly alternate with each other. Fine-scale oscillatory zoning is revealed in several zircons (e.g., grain 7.1, Fig. 3 ), which is commonly considered as being a magmatic signature (e.g., Corfu et al., 2003).

All 15 dated zircon grains plot on a discordia line with an upper intercept with a concordia curve at $2810 \pm 4$ Ma and a lower intercept at $590 \pm 83 \mathrm{Ma}(\mathrm{MSWD}=1.5$; Fig. 4). With the exception of three spots $(6.1,14.1$ and 11.1 with discordance values of $9 \%, 15 \%$, and $20 \%$ respectively), all other points are clustered in the region of the upper discordia intercept and are considered subconcordant with the values of discordance not greater than $6 \%$ (Table 1).

Table 1 U-Pb and oxygen isotope data for zircons from the gabbro-diorite of the Shaka Ridge (sample F-B-2016-3-2-55)

\begin{tabular}{|c|c|c|c|c|c|c|c|c|c|c|c|c|c|c|c|c|c|}
\hline \multirow{2}{*}{$\begin{array}{l}\text { Spot } \\
1.1\end{array}$} & \multirow{2}{*}{$\begin{array}{c}{ }^{206} \mathrm{~Pb}_{\mathrm{c}} \\
(\%)\end{array}$} & \multirow{2}{*}{$\begin{array}{c}\mathrm{U}(\mathrm{ppm}) \\
567\end{array}$} & \multirow{2}{*}{$\begin{array}{c}\begin{array}{c}\text { Th } \\
(\mathrm{ppm})\end{array} \\
556\end{array}$} & \multirow{2}{*}{$\begin{array}{c}{ }^{232} \mathrm{Th} / \\
{ }^{238} \mathrm{U} \\
1.01\end{array}$} & \multirow{2}{*}{$\begin{array}{c}\begin{array}{r}{ }^{206} \mathrm{~Pb}^{*} \\
(\mathrm{ppm})\end{array} \\
263\end{array}$} & \multicolumn{2}{|c|}{$\begin{array}{c}{ }^{206} \mathrm{~Pb} /{ }^{238} \mathrm{U} \text { age } \\
(\mathrm{Ma}), \pm \sigma\end{array}$} & \multicolumn{2}{|c|}{$\begin{array}{c}{ }^{207} \mathrm{~Pb} /{ }^{206} \mathrm{~Pb}(\mathrm{Ma}) \\
\pm \sigma\end{array}$} & \multirow{2}{*}{$\begin{array}{c}D(\%) \\
1\end{array}$} & \multirow{2}{*}{$\begin{array}{c}{ }^{207} \mathrm{~Pb} /{ }^{235} \mathrm{U} \\
14.75\end{array}$} & \multirow{2}{*}{$\begin{array}{c} \pm \sigma(\%) \\
0.5\end{array}$} & \multirow{2}{*}{$\begin{array}{c}{ }^{206} \mathrm{~Pb} /{ }^{238} \mathrm{U} \\
0.539\end{array}$} & \multirow{2}{*}{$\begin{array}{c} \pm \sigma(\%) \\
0.4\end{array}$} & \multirow{2}{*}{$\begin{array}{c}\rho \\
0.730\end{array}$} & \multirow{2}{*}{$\begin{array}{l}\delta^{18} \mathrm{O} \\
(\% 0) \\
3.04\end{array}$} & \multirow{2}{*}{$\begin{array}{r}2 \mathrm{SE} \\
(\%) \\
0.16\end{array}$} \\
\hline & & & & & & 2779 & \pm 9 & 2813 & \pm 6 & & & & & & & & \\
\hline 2.1 & 0.00 & 683 & 686 & 1.04 & 311 & 2743 & \pm 9 & 2801 & \pm 12 & 2 & 14.40 & 0.8 & 0.530 & 0.4 & 0.470 & 2.98 & 0.15 \\
\hline 3.1 & 0.01 & 480 & 461 & 0.99 & 229 & 2845 & \pm 9 & 2812 & \pm 6 & -1 & 15.16 & 0.5 & 0.555 & 0.4 & 0.732 & 2.11 & 0.27 \\
\hline 4.1 & 0.00 & 779 & 5857 & 7.77 & 381 & 2902 & \pm 7 & 2819 & \pm 12 & -3 & 15.61 & 0.8 & 0.569 & 0.3 & 0.377 & 2.56 & 0.22 \\
\hline 5.1 & 0.01 & 2093 & 3321 & 1.64 & 920 & 2663 & \pm 6 & 2783 & \pm 3 & 5 & 13.74 & 0.3 & 0.511 & 0.3 & 0.821 & 1.75 & 0.14 \\
\hline 6.1 & 0.02 & 499 & 287 & 0.59 & 208 & 2551 & \pm 9 & 2775 & \pm 7 & 9 & 12.97 & 0.6 & 0.485 & 0.4 & 0.718 & 2.03 & 0.19 \\
\hline 7.1 & 0.01 & 1825 & 2424 & 1.37 & 805 & 2670 & \pm 6 & 2794 & \pm 3 & 5 & 13.88 & 0.3 & 0.513 & 0.3 & 0.809 & 2.69 & 0.23 \\
\hline 8.1 & 0.01 & 819 & 866 & 1.09 & 372 & 2739 & \pm 7 & 2806 & \pm 4 & 2 & 14.42 & 0.4 & 0.529 & 0.3 & 0.740 & 3.15 & 0.15 \\
\hline 9.1 & 0.02 & 1122 & 1216 & 1.12 & 535 & 2843 & \pm 6 & 2813 & \pm 4 & -1 & 15.16 & 0.3 & 0.554 & 0.3 & 0.759 & 2.93 & 0.28 \\
\hline 10.1 & 0.01 & 947 & 998 & 1.09 & 433 & 2747 & \pm 6 & 2808 & \pm 4 & 2 & 14.49 & 0.4 & 0.531 & 0.3 & 0.743 & 2.98 & 0.15 \\
\hline 11.1 & 0.06 & 318 & 277 & 0.90 & 117 & 2294 & \pm 8 & 2743 & \pm 7 & 20 & 11.20 & 0.6 & 0.427 & 0.4 & 0.671 & 3.04 & 0.18 \\
\hline 12.1 & 0.01 & 1153 & 1332 & 1.19 & 506 & 2660 & \pm 17 & 2798 & \pm 8 & 5 & 13.85 & 0.9 & 0.511 & 0.8 & 0.843 & 3.00 & 0.18 \\
\hline 13.1 & 0.03 & 280 & 170 & 0.63 & 121 & 2624 & \pm 11 & 2794 & \pm 7 & 6 & 13.59 & 0.7 & 0.503 & 0.5 & 0.745 & 2.90 & 0.13 \\
\hline 14.1 & 0.04 & 389 & 381 & 1.01 & 152 & 2414 & \pm 8 & 2770 & \pm 7 & 15 & 12.11 & 0.5 & 0.454 & 0.4 & 0.685 & 2.53 & 0.25 \\
\hline 15.1 & 0.02 & 943 & 1031 & 1.13 & 431 & 2749 & \pm 7 & 2809 & \pm 4 & 2 & 14.51 & 0.4 & 0.532 & 0.3 & 0.785 & 2.96 & 0.13 \\
\hline
\end{tabular}

Errors are $1 \sigma ; \mathrm{Pb}_{c}$ and $\mathrm{Pb} *$ indicate the common and radiogenic portions, respectively; error in standard calibration was $0.36 \%$ (not included in above errors but required when comparing data from different mounts); common $\mathrm{Pb}$ corrected using measured ${ }^{204} \mathrm{~Pb} . D(\%)$ discordancy: $D=100 \times\{[\mathrm{Age}$ $\left.\left.\left({ }^{207} \mathrm{~Pb} /{ }^{206} \mathrm{~Pb}\right)\right] /\left[\mathrm{Age}\left({ }^{206} \mathrm{~Pb} /{ }^{238} \mathrm{U}\right)\right]-1\right\}$. 


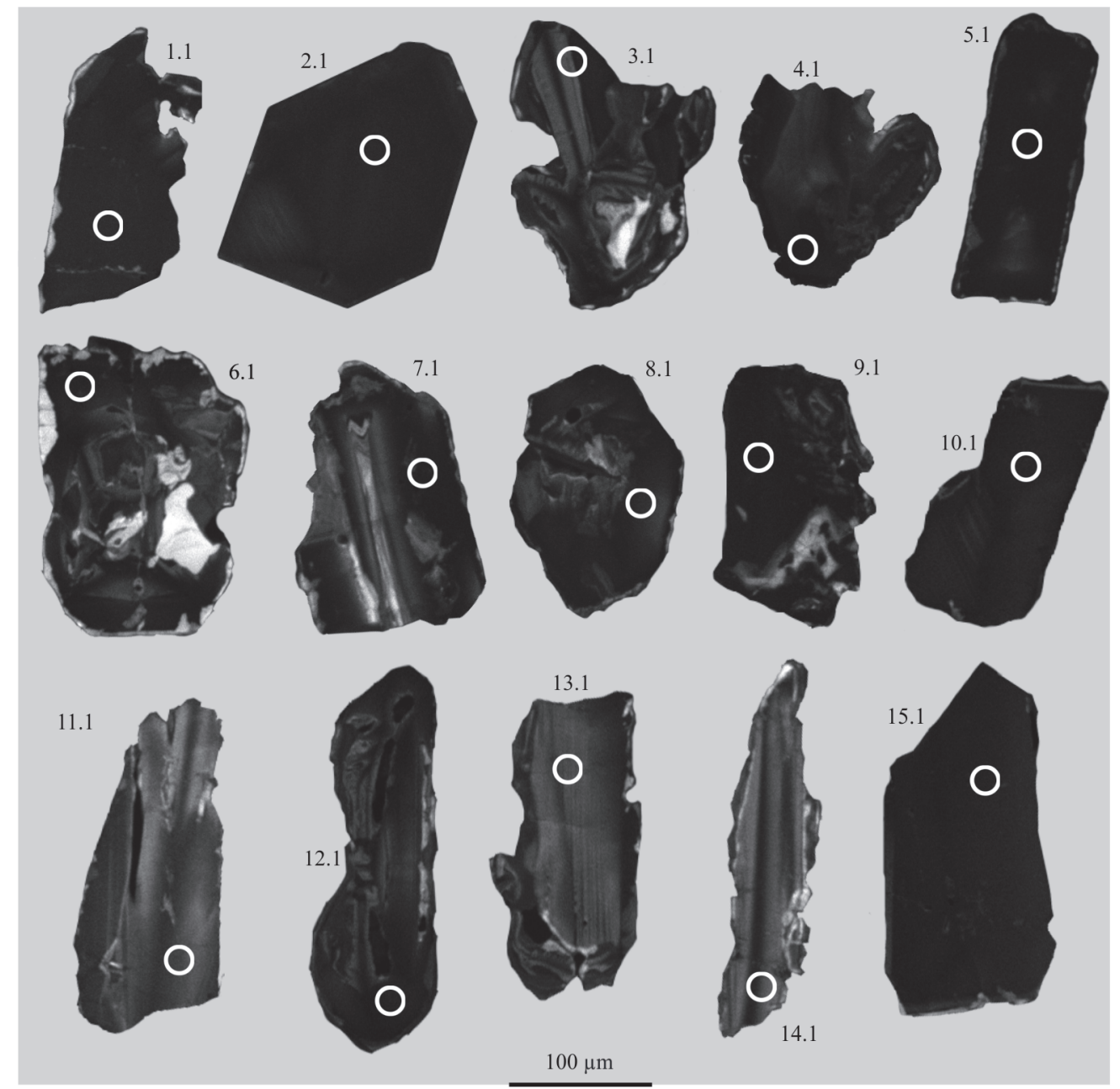

Figure 3. Cathodoluminescence (CL) photomicrographs of zircons from sample F-B-2016-3-2-55 (ion microprobe crater is about $20 \mu \mathrm{m}$ ).

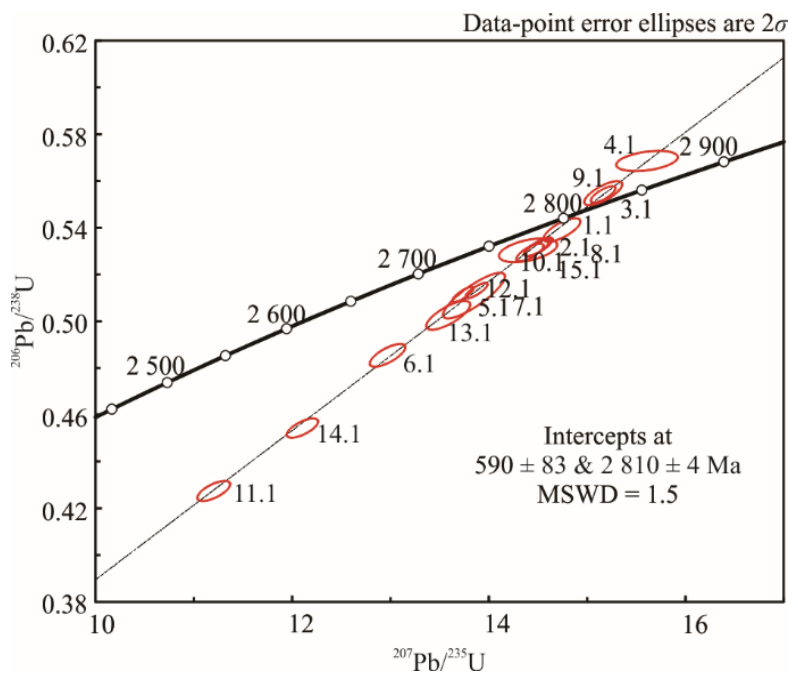

Figure 4. Wetherill concordia diagram for zircons from sample F-B-2016$3-2-55$.

The content of $U$ in the zircon suite ranges from $280 \mathrm{ppm}$ to $2093 \mathrm{ppm}$ (with an average of $860 \mathrm{ppm}$ ). It should be noted that the three most discordant zircons (spots 6.1, 14.1 and 11.1) show U abundances (318 ppm to $499 \mathrm{ppm}$ ) not exceeding those established in the subconcordant zircons. Thorium varies in a wider range than $U$ (170 ppm-5 $857 \mathrm{ppm}$, with an average of $1324 \mathrm{ppm})$. The Th contents of the three most discordant grains are also far from the established maximum values and do not exceed the average value, varying from $277 \mathrm{ppm}$ to $381 \mathrm{ppm}$. The $\mathrm{Th} / \mathrm{U}$ ratios in the examined zircons are between 0.59 and 7.77 , averaging 1.51 .

The isotopic composition of oxygen in zircons is characterized by relatively low values of $\delta^{18} \mathrm{O}$ from $1.75 \%$ to $3.15 \%$, averaging $2.71 \%$ (Table 1 ).

The total abundance of REE in the studied grains varies from $960 \mathrm{ppm}$ to $4815 \mathrm{ppm}$, with an average of $2591 \mathrm{ppm}$ $\left(\mathrm{Lu}_{\mathrm{N}} / \mathrm{La}_{\mathrm{N}}\right.$ ratio averages 4 659; Table 2). In general, the REE distribution patterns are fractionated with a gradual increase in chondrite-normalized values from light to heavy REE (Fig. 5). Note that the REE patterns exhibit a very similar shape in the HREE region, differing only in the overall HREE content. The $\mathrm{Lu}_{\mathrm{N}} / \mathrm{Gd}_{\mathrm{N}}$ ratio characterizing the degree of HREE slope is fairly consistent and varies from 14.5 to 28.6 with an average value of 18.8. By contrast, the concentrations of LREE show much more variability. The total LREE content varies from $23 \mathrm{ppm}$ to $252 \mathrm{ppm}$, with an average of $75 \mathrm{ppm}$. In zircons with the highest LREE content (spots 4.1 and 7.1), the REE distribution spectra in the LREE region show a flattened (unfractionated) 
Table 2 Trace elements concentrations (ppm) in zircons from the gabbro-diorite of the Shaka Ridge (sample F-B-2016-3-2-55)

\begin{tabular}{|c|c|c|c|c|c|c|c|c|c|c|c|c|c|c|c|}
\hline Spot & 1.1 & 2.1 & 3.1 & 4.1 & 5.1 & 6.1 & 7.1 & 8.1 & 9.1 & 10.1 & 11.1 & 12.1 & 13.1 & 14.1 & 15.1 \\
\hline $\mathrm{La}$ & 0.11 & 0.31 & 0.64 & 29.4 & 0.74 & 0.64 & 6.70 & 2.82 & 0.32 & 0.22 & 0.30 & 5.54 & 0.08 & 1.51 & 0.19 \\
\hline $\mathrm{Ce}$ & 35.3 & 40.1 & 28.3 & 143 & 87.9 & 31.9 & 105 & 43.5 & 43.7 & 42.4 & 19.3 & 74.9 & 21.4 & 24.8 & 38.4 \\
\hline $\operatorname{Pr}$ & 0.52 & 0.87 & 0.28 & 12.6 & 1.83 & 0.48 & 5.99 & 1.98 & 1.08 & 0.94 & 0.63 & 3.33 & 0.13 & 1.13 & 0.94 \\
\hline $\mathrm{Nd}$ & 8.47 & 11.1 & 4.41 & 66.4 & 21.6 & 4.07 & 45.0 & 17.1 & 14.8 & 12.3 & 9.39 & 20.0 & 1.50 & 9.58 & 12.7 \\
\hline $\mathrm{Sm}$ & 17.0 & 18.7 & 6.98 & 21.2 & 29.9 & 5.52 & 34.6 & 15.0 & 22.7 & 21.5 & 13.3 & 15.5 & 3.59 & 10.9 & 18.3 \\
\hline $\mathrm{Eu}$ & 0.28 & 0.29 & 0.90 & 3.01 & 0.38 & 0.33 & 1.50 & 1.12 & 0.36 & 0.43 & 0.42 & 2.86 & 0.12 & 1.19 & 0.21 \\
\hline Gd & 84.3 & 98.3 & 37.9 & 67.3 & 163 & 29.5 & 162 & 68.9 & 137 & 121 & 63.5 & 60.5 & 21.9 & 48.1 & 109 \\
\hline Dy & 340 & 402 & 162 & 257 & 692 & 128 & 625 & 280 & 563 & 468 & 259 & 255 & 104 & 186 & 458 \\
\hline $\mathrm{Er}$ & 636 & 795 & 335 & 603 & 1371 & 296 & 1243 & 572 & 1099 & 951 & 517 & 562 & 253 & 402 & 927 \\
\hline $\mathrm{Yb}$ & 1053 & 1274 & 622 & 1356 & 2131 & 591 & 2062 & 975 & 1715 & 1465 & 837 & 979 & 477 & 707 & 1525 \\
\hline $\mathrm{Lu}$ & 154 & 188 & 96 & 227 & 317 & 96 & 309 & 144 & 252 & 217 & 130 & 149 & 77 & 110 & 230 \\
\hline $\mathrm{Li}$ & 7.47 & 4.24 & 11.4 & 41.5 & 28.8 & 17.4 & 25.6 & 12.8 & 13.3 & 9.52 & 6.66 & 35.4 & 15.2 & 11.5 & 11.7 \\
\hline $\mathrm{P}$ & 449 & 511 & 332 & 259 & 1022 & 321 & 869 & 425 & 744 & 632 & 422 & 649 & 389 & 352 & 629 \\
\hline $\mathrm{Ca}$ & 74.7 & 56.5 & 27.9 & 185 & 16.2 & 24.2 & 44.3 & 97.7 & 12.2 & 17.7 & 18.1 & 177 & 21.7 & 59.4 & 22.6 \\
\hline $\mathrm{Ti}$ & 24.9 & 19.1 & 15.5 & 53.7 & 40.6 & 14.0 & 27.1 & 17.1 & 25.1 & 25.1 & 28.8 & 20.5 & 14.2 & 20.1 & 17.6 \\
\hline $\mathrm{Sr}$ & 1.17 & 1.04 & 3.13 & 5.50 & 1.56 & 0.97 & 2.49 & 1.97 & 1.69 & 1.62 & 0.88 & 2.08 & 1.36 & 1.16 & 1.98 \\
\hline Y & 3904 & 4755 & 2010 & 3011 & 8483 & 1784 & 7108 & 3179 & 6665 & 5439 & 2858 & 3250 & 1418 & 2245 & 5536 \\
\hline $\mathrm{Nb}$ & 89.1 & 78.2 & 88.9 & 68.7 & 108 & 56.9 & 62.9 & 55.3 & 49.5 & 43.5 & 25.9 & 52.3 & 27.3 & 29.2 & 40.0 \\
\hline $\mathrm{Ba}$ & 5.09 & 5.04 & 286 & 6.78 & 2.12 & 2.66 & 4.28 & 5.37 & 3.62 & 3.34 & 1.86 & 2.43 & 1.30 & 3.62 & 4.16 \\
\hline Hf & 10708 & 10166 & 11650 & 9824 & 9970 & 11752 & 11213 & 10892 & 9994 & 9355 & 9531 & 11224 & 10727 & 9762 & 10596 \\
\hline Th & 595 & 786 & 351 & 4886 & 3175 & 343 & 2331 & 622 & 1284 & 1017 & 298 & 1432 & 176 & 301 & 1065 \\
\hline $\mathrm{U}$ & 781 & 1046 & 595 & 2120 & 2677 & 737 & 2370 & 889 & 1569 & 1307 & 488 & 1587 & 425 & 526 & 1374 \\
\hline $\mathrm{Th} / \mathrm{U}$ & 0.76 & 0.75 & 0.59 & 2.31 & 1.19 & 0.47 & 0.98 & 0.70 & 0.82 & 0.78 & 0.61 & 0.90 & 0.41 & 0.57 & 0.78 \\
\hline $\mathrm{Eu} / \mathrm{Eu}^{*}$ & 0.02 & 0.02 & 0.17 & 0.24 & 0.02 & 0.08 & 0.06 & 0.11 & 0.02 & 0.03 & 0.04 & 0.29 & 0.04 & 0.16 & 0.01 \\
\hline $\mathrm{Ce} / \mathrm{Ce}^{*}$ & 35.2 & 18.6 & 16.1 & 1.80 & 18.3 & 13.8 & 4.00 & 4.45 & 18.0 & 22.8 & 10.7 & 4.22 & 50.2 & 4.58 & 22.3 \\
\hline$\Sigma \mathrm{REE}$ & 2329 & 2829 & 1295 & 2786 & 4815 & 1183 & 4599 & 2122 & 3850 & 3300 & 1850 & 2127 & 960 & 1503 & 3319 \\
\hline$\Sigma$ LREE & 44.4 & 52.4 & 33.6 & 252 & 112 & 37.1 & 162 & 65.4 & 59.9 & 55.9 & 29.7 & 104 & 23.1 & 37.0 & 52.3 \\
\hline$\Sigma$ HREE & 2267 & 2757 & 1254 & 2511 & 4673 & 1140 & 4401 & 2040 & 3767 & 3222 & 1806 & 2005 & 933 & 1454 & 3248 \\
\hline $\mathrm{Lu}_{\mathrm{N}} / \mathrm{La}_{\mathrm{N}}$ & 13024 & 5752 & 1439 & 74.4 & 4122 & 1432 & 444 & 491 & 7585 & 9647 & 4137 & 260 & 8798 & 700 & 11973 \\
\hline $\mathrm{Lu}_{\mathrm{N}} / \mathrm{Gd}_{\mathrm{N}}$ & 14.8 & 15.4 & 20.6 & 27.3 & 15.7 & 26.3 & 15.4 & 16.9 & 14.9 & 14.5 & 16.5 & 20.0 & 28.6 & 18.4 & 17.1 \\
\hline $\mathrm{Sm}_{\mathrm{N}} / \mathrm{La}_{\mathrm{N}}$ & 238 & 95.2 & 17.3 & 1.15 & 64.6 & 13.7 & 8.26 & 8.51 & 113 & 159 & 70.3 & 4.47 & 67.9 & 11.6 & 158 \\
\hline$T(\mathrm{Ti})\left({ }^{\circ} \mathrm{C}\right)$ & 831 & 804 & 783 & 917 & 884 & 774 & 839 & 793 & 831 & 831 & 846 & 811 & 775 & 808 & 796 \\
\hline
\end{tabular}

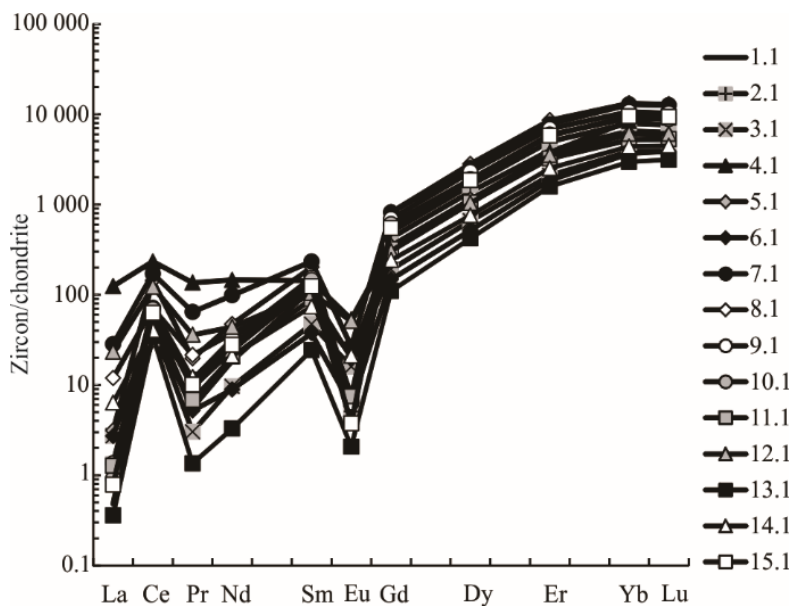

Figure 5. REE distribution spectra of zircons from sample F-B-2016-3-255 normalized to chondrite CI (McDonough and Sun, 1995). character, which is reflected in low $\mathrm{Sm}_{\mathrm{N}} / \mathrm{La}_{\mathrm{N}}$ ratios (1.15 and 8.26 , respectively).

The REE patterns of the zircons exhibit positive Ce anomalies and negative $\mathrm{Eu}$ anomalies. Note that a negative correlation is observed between the values of a positive Ce anomaly (Ce/Ce* ratio) and the total LREE abundances $(r=-0.5)$. At spot 4.1 having the highest LREE content of $252 \mathrm{ppm}$, there is virtually no positive $\mathrm{Ce}$ anomaly $\left(\mathrm{Ce} / \mathrm{Ce}^{*}=1.15\right)$. By contrast, in zircons showing low LREE levels, the positive Ce anomaly is most pronounced. For instance, spot 13.1 with the total LREE concentration of only $23 \mathrm{ppm}$ shows the most prominent positive $\mathrm{Ce}$ anomaly $\left(\mathrm{Ce} / \mathrm{Ce}^{*}=50.2\right)$.

The magnitude of a negative Eu anomaly varies from 0.01 to 0.29 with an average $\mathrm{Eu} / \mathrm{Eu}^{*}$ value of 0.09 . In zircons with a high content of LREE and flat LREE distribution patterns, small negative Eu anomalies are observed, whereas zircons with a fractionated distribution of both REE (total) and LREE demonstrate well-developed negative Eu anomalies. Hence, a positive correlation is observed between the values of the posi- 
tive $\mathrm{Ce}$ and negative Eu anomalies $(r=0.57)$; i.e., zircons with a well-developed positive $\mathrm{Ce}$ anomaly also demonstrate a prominent negative Eu anomaly.

Hafnium abundances in the analyzed zircons are rather high and vary in a narrow range from $9355 \mathrm{ppm}$ to 11751 ppm, with an average of $10491 \mathrm{ppm}$. The content of $\mathrm{Y}$ ranges from $1418 \mathrm{ppm}$ to $8483 \mathrm{ppm}$ (with an average of $4110 \mathrm{ppm}$ ) and shows a strong positive correlation with the total HREE content $(r=0.99)$. The concentration of $\mathrm{P}$, varying from 259 ppm to $1022 \mathrm{ppm}$, positively correlates with $\mathrm{Y}(r=0.92)$ and HREE $(r=0.88)$ levels, which is consistent with the xenotimetype substitution $(\mathrm{Y}, \mathrm{REE})^{3+}+\mathrm{P}^{5+}=\mathrm{Zr}^{4+}+\mathrm{Si}^{4+}$ (Finch and Hanchar, 2003).

Some zircon grains display increased abundances of nonformula elements. Calcium content varies from $12 \mathrm{ppm}$ to 185 ppm, averaging $57 \mathrm{ppm}$. An increased $\mathrm{Ca}$ is characteristic of zircons with small positive $\mathrm{Ce}$ and negative $\mathrm{Eu}$ anomalies as well as with higher LREE content $(r=0.64)$. Strontium varies from $0.9 \mathrm{ppm}$ to $5.5 \mathrm{ppm}$, with an average of $1.9 \mathrm{ppm}$. Ti content is between $14 \mathrm{ppm}$ and $54 \mathrm{ppm}$, with an average of 24 ppm, which corresponds to a crystallization temperature range of $774-917^{\circ} \mathrm{C}$ (average value of $821^{\circ} \mathrm{C}$ ) using the equation of Watson et al. (2006).

\section{DISCUSSION}

Grimes et al. $(2015,2009,2007)$ demonstrated that the origin of zircons that crystallized from melts in continental and oceanic settings can be revealed based on their $\mathrm{Yb}, \mathrm{U}, \mathrm{Y}$ and Hf abundances. The examined zircon xenocrysts from gabbrodiorites of the Shaka Ridge (sample F-B-2016-3-2-55) have been plotted in the discrimination diagrams with outlined fields for oceanic and continental zircons (Fig. 6). In the $\mathrm{Y}$ vs. $\mathrm{U} / \mathrm{Yb}$ binary plot (Fig. 6a), all the zircon compositions fall within the continental field. About half of the grains are located within the compositional area of zircons from continental granitoids, identified according to Ballard et al. (2002) and Belousova et al. (2006). In the Yb vs. U (Fig. 6b) and Hf vs. U/Yb (Fig. 6c) discrimination diagrams, all the zircon points plot into the area of zircons of continental origin as well. In the discrimination diagrams proposed by Belousova et al. (2002), the zircon population belongs to the compositional field of zircons from granitoids (in $\mathrm{Yb} / \mathrm{Sm}$ vs. Y plot, Fig. 7a), or to the field of granitoids and partially to the field of zircons from syenites and associated pegmatites (in Ce/Ce* vs. Y plot, Fig. 7b).

Another effective criterion for the discrimination of zircon origin is the concentration of Li (Bouvier et al., 2012; Ushikubo et al., 2008). Zircons from rocks of oceanic crust are characterized by an extremely low Li content (less than $0.01 \mathrm{ppm}$ ), while continental crust zircons, as a rule, show much higher $\mathrm{Li}$ abundances in the range of 1 ppm-100 ppm (Grimes et al., 2011; Ushikubo et al., 2008). In the studied zircons, Li varies from $1.8 \mathrm{ppm}$ to $50 \mathrm{ppm}$ with an average of $16 \mathrm{ppm}$ (Table 2), which makes it possible to unambiguously assign our samples to zircons of continental crust.

In the $\mathrm{La}$ vs. $\mathrm{Sm}_{\mathrm{N}} / \mathrm{La}_{\mathrm{N}}$ space (Fig. 8) with the outlined compositional fields of unaltered magmatic, hydrothermal, and porous zircons (Bouvier et al., 2012; Fu et al., 2009; Grimes et al., 2009; Hoskin, 2005), the studied zircon xenocrysts com-
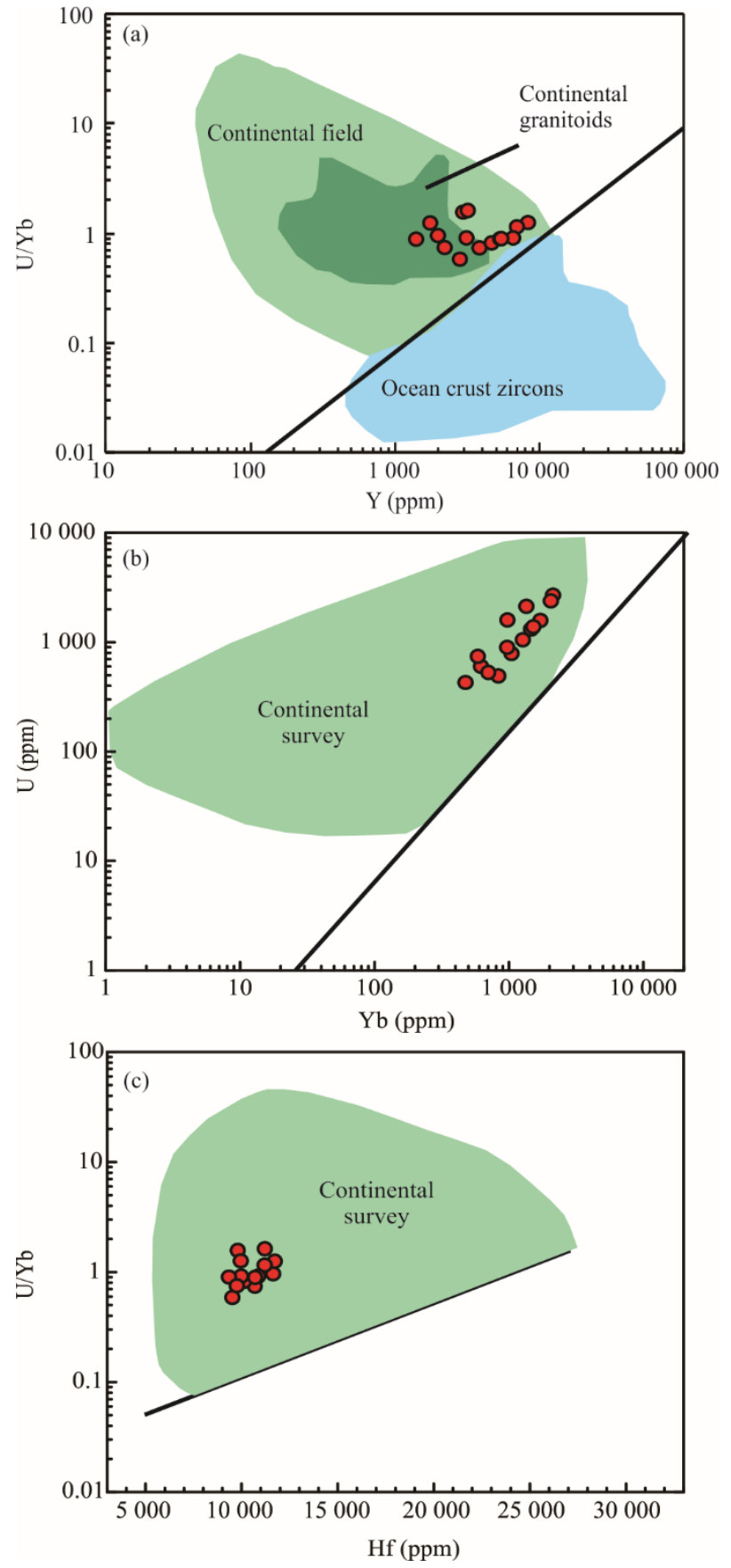

Figure 6. The U/Yb-based zircon discrimination diagrams modified after Grimes et al. (2015, 2007). (a) Y vs. U/Yb. The granitoid field comprises zircon analyses from northern Chile and eastern Australia (Belousova et al., 2006; Ballard et al., 2002); (b) Yb vs. U; (c) Hf vs. U/Yb. The compositions of zircons from sample F-B-2016-3-2-55 are shown by red circles.

prise a single trend with a clear negative correlation between these two geochemical parameters. Of these, eight spots (1.1, $2.1,5.1,9.1,10.1,11.1,13.1,15.1)$ unambiguously plot into the field of unaltered magmatic zircons, while six spots are located either within the overlap between the field of unaltered magmatic zircons and the field of porous zircons (spots 3.1, $6.1,14.1$ ) or in the area of porous zircons (spots 7.1, 8.1, 12.1). One grain with the highest La content (spot 4.1, Table 2) is located at the border between the fields of porous and hydrother- 
mal zircons. Taking into account that porous zircons are considered by some authors as a variety of hydrothermal zircons (Fu et al., 2009; Kirkland et al., 2009), the proportion of altered zircons among the xenocrysts may be more significant.

Therefore, a series of crucial geochemical signatures of the zircons from gabbro-diorites of the Shaka Ridge region (fractionated REE distribution patterns with a positive slope in chondrite-normalized values from light to heavy REE, positive $\mathrm{Ce}$ anomalies and negative $\mathrm{Eu}$ anomalies, high $\mathrm{Th} / \mathrm{U}$ ratios, trace-element geochemistry) indicate the zircons to be of magmatic origin and have been derived from rocks of continental crust, mostly from granitoids (e. g., Balashov and Skublov, 2011; Hoskin and Schaltegger, 2003). These zircons were inherited from much older rocks $(\sim 2.8 \mathrm{Ga})$ with respect to the gabbro-diorite and thus represent genuine xenocrysts. Before being transported into young oceanic crust, the zircons had undergone a thermal influence (probably, metamorphism) with an age of $\sim 600$ Ma recorded by a lower discordia intercept (Fig. 4). The increased LREE contents and the flattened normalized LREE distribution spectra in some zircon grains are explained by that metamorphic fluids perhaps exerted some effect on the
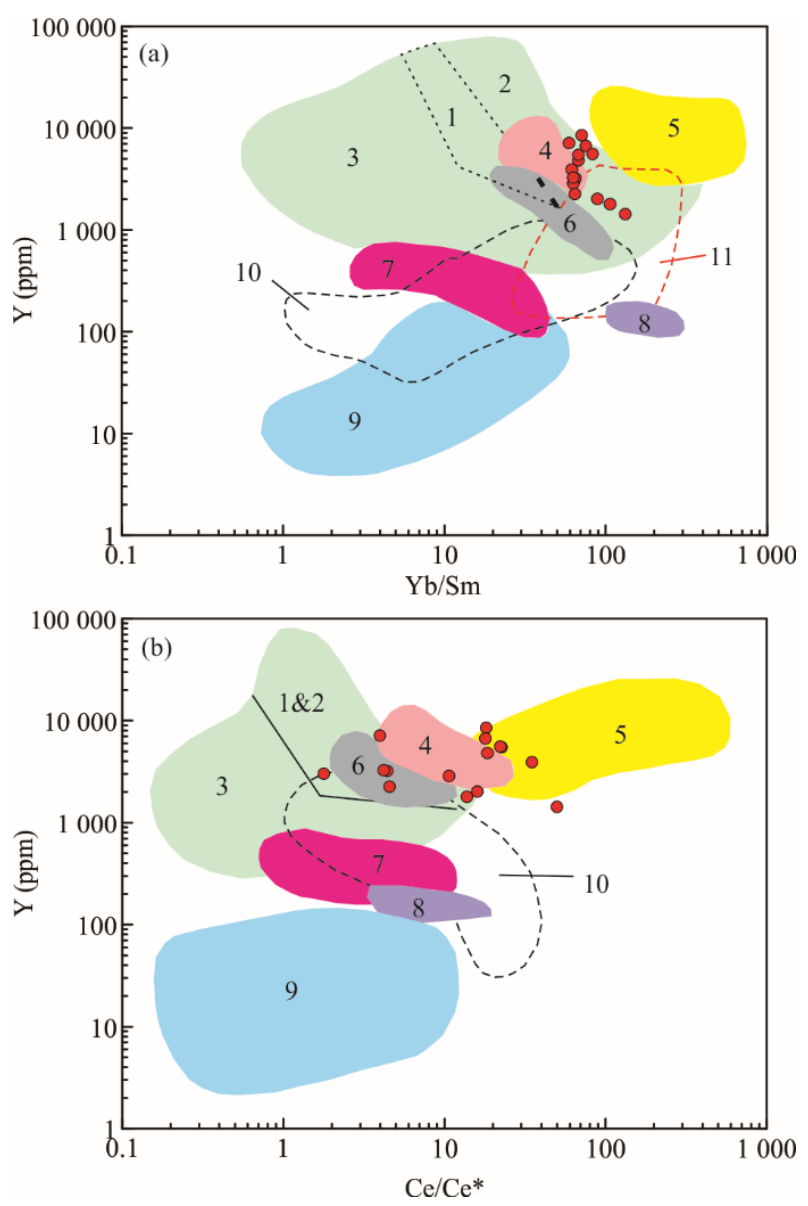

Figure 7. (a) $\mathrm{Yb} / \mathrm{Sm}$ vs. $\mathrm{Y}$ and (b) $\mathrm{Ce} / \mathrm{Ce}$ * vs. $\mathrm{Y}$ discriminant diagrams. The fields of zircon compositions used as discriminants for different rock types are after Belousova et al. (2002). 1. Aplites, leucogranites; 2. granites; 3. granodiorites and tonalities; 4 . larvikites; 5 . nepheline syenite and syenite pegmatite; 6. syenite pegmatites; 7. carbonatites; 8. syenites; 9. kimberlites; 10. lamproites; 11. mafic rocks. The compositions of zircons from sample FB-2016-3-2-55 are shown by red circles. geochemical characteristics of the zircons during this thermal event. The fluids also increased the Ca concentration in the zircons; this signature of fluid impact on zircon has been reported previously (e.g., Geisler and Schleicher, 2000).

Alternatively, such a marked increase in $\mathrm{Ca}$ and LREE concentrations in some zircon grains could have been caused by high-temperature hydrothermal alterations within young oceanic crust. There are also other indicators of zircon alteration during their residence in the oceanic crust. It is likely hydrothermal fluid influence that affected the La vs. $\mathrm{Sm}_{\mathrm{N}} / \mathrm{La}_{\mathrm{N}}$ systematics (Fig. 8) and decreased the $\delta^{18} \mathrm{O}$ values down to $1.75 \%$ - $3.15 \%$ o (Table 1). Submarine hydrothermal solutions related to volcanic activity have high LREE/HREE and low Sm/La ratios (Bau and Dulski, 1999; Michard and Albarède, 1986) and thus could have contributed to the observed increase of LREE concentrations in some zircon grains. The values of $\delta^{18} \mathrm{O}$ in the examined zircons are lower than typical values for mantle zircons of about 5.3\% (Valley et al., 1998), which strongly implies the influence of hydrothermal fluid flow (Bindeman, 2008). $\delta^{18} \mathrm{O}$ values in the range of $0-6 \%$ are typical for minerals from rocks belonging to the lower layer of oceanic crust that is composed of gabbro (Korolev et al., 2018; Valley et al., 2005; Eiler, 2001). Previously, it has been suggested that high-temperature (over $300{ }^{\circ} \mathrm{C}$ ) hydrothermal alterations may lead to a decrease of $\delta^{18} \mathrm{O}$ in minerals, including zircon, from the rocks of this layer with respect to mantle values (e.g., Korolev et al., 2018; Eiler, 2001; Gregory and Taylor, 1981). By contrast, zircon from oceanic plagiogranites and gabbros in the MidAtlantic and SWIR areas that is unaffected by submarine hydrothermal solutions is characterized by a rather narrow $\delta^{18} \mathrm{O}$ interval with an average value of $5.2 \% 0 \pm 0.5 \%$, indicating isotopicgeochemical equilibrium with MORB (Grimes et al., 2011).

It is challenging at this stage of research to give an unambiguous answer to the urgent question- how were the continentderived zircons delivered into oceanic igneous rocks in the vicinity of the SWIR? Over the past two decades, a number of hypotheses have been put forward to explain the unusual find-

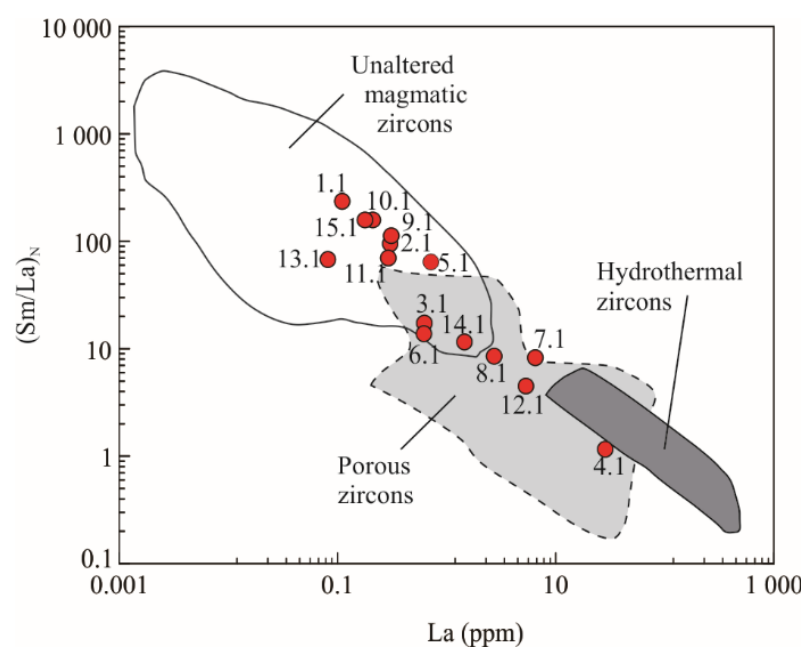

Figure 8. $(\mathrm{Sm} / \mathrm{La})_{\mathrm{N}}$ vs. La $(\mathrm{ppm})$ discriminant diagram. Compositional fields are after Hoskin (2005), Grimes et al. (2009), Fu et al. (2009), Bouvier et al. (2012). The compositions of zircons from sample F-B-2016-3-2-55 are shown by red circles. 
ings of continent-derived zircons in oceanic-floor magmatic rocks. A pioneer study of Pilot et al. (1998) proposed two plausible interpretations to explain the occurrence of unusually old zircons ( 330 and $\sim 1600 \mathrm{Ma}$ ) near the Kane fracture zone in the Mid-Atlantic Ridge. During the Atlantic opening, fragmented crustal material sank into small circulation cells that developed in the shallow mantle at each side of the ridge axis, and this material was transported through these cells to the ridge axis (Pilot et al., 1998). Alternatively, continental crustal material has been entrapped in the Kane fracture zone since the Atlantic opening as a result of repeated ridge jumping and transform migration (oscillatory spreading), with some of this material subsequently migrating down the ridge axis (Pilot et al., 1998).

The study of Bea et al. (2020), which summarizes a significant number of older-than-host zircon xenocryst samples (190 Ma to $3 \mathrm{Ga}$ ) in oceanic rocks of the Atlantic, suggested that the source of ancient xenocrysts are fragments of continental crust preserved in the vicinity of the mid-ocean ridge. Upwelling mafic magma can scavenge continental xenoliths, disintegrating them, and thus releasing zircon xenocrysts. Alternatively, it is assumed that hot mafic magma penetrating zircon-containing oceanic plagiogranites or fragments of continental crust may locally heat these rocks above the solidus. As a result of this process, patches of low-temperature silicate magma enriched with zircon are formed, which then migrate and mix with the rapidly rising magma of mafic composition (Bea et al., 2020 and references therein).

For the Indian Ocean, there are few reports dealing with findings of ancient zircon xenocrysts. The occurrences of Proterozoic (660-840 and >1 $971 \mathrm{Ma}$; Torsvik et al., 2013) and Archaean (2.5-3.0 Ga; Ashwal et al., 2017) zircons on the Island of Mauritius were ascribed to zircon assimilation from ancient fragments of continental lithosphere beneath Mauritius and subsequent transportation to the surface by plume-related lavas (Ashwal et al., 2017; Torsvik et al., 2013). In the work by Cheng et al. (2016), two possibilities for the origin of Jurassic ( $\sim 180 \mathrm{Ma})$ zircons in gabbroid rocks of the SWIR are considered: (1) the preservation of an intact Gondwana fragment on the ocean floor; (2) the occurrence of a partially altered continental relic that once resided in shallow regions of the upper mantle, and was entrained and transported to the vicinity beneath the axis.

From these examples, it is obvious that a convincing and unambiguous interpretation of the origin of unusually old zircons in young oceanic rocks has not yet appeared; it is also difficult to verify the explanations (Cheng et al., 2016). Note that the zircons examined in these papers span a very broad range of crystallization age (from $180 \mathrm{Ma}$ to $3 \mathrm{Ga}$ ), which indicates their derivation from very different continental sources. In general, there is a series of major factors possibly responsible for the zircon transportation, such as a long-lived subduction zone, generation of mantle plumes, Atlantic opening, Gondwana supercontinent breakup, and further melting of small continental blocks of the sub-Gondwana lithosphere containing an ancient zircon component. However, many authors agree that the preservation of ancient continental fragments in the vicinity of a ridge axis is a necessary requirement for the transportation of zircons to occur. Taking into account the complex geological history of the study area, geochemical characteristics of the zircon xenocrysts examined here, and petrochemical characteristics of the host gabbro-diorite sample (high LILE, low HFSE), it appears that the zircons were captured as xenocrysts during the formation and migration of parental for the gabbro-diorite melts. Some authors provided strong evidence for the presence of the remains of the sub-Gondwana lithospheric mantle in the form of xenoliths and schlieren within modern oceanic lithosphere (Frey et al., 2002; le Roux et al., 2002; Kamenetsky et al., 2001; Douglass et al., 1999). We suggest that small blocks of continental crust after the Gondwana breakup could have survived in younger oceanic lithosphere and became involved in melting processes. The exact mechanism of crystal recycling into the mantle, however, is yet to be constrained. The continuing discoveries of ancient zircon in the mid-ocean ridges and deep ocean basins will shed additional light on this urgent issue.

\section{CONCLUSIONS}

(1) For the first time, zircon in gabbro-diorites of the Shaka Ridge was described. The U-Pb isotope system of the zircons records a crystallization age of $\sim 2.8 \mathrm{Ga}$ and an age of a superimposed thermal event (metamorphism?) of $\sim 600 \mathrm{Ma}$.

(2) Zircon grains show geochemical signatures revealing their magmatic origin, i.e., fractionated REE distribution patterns (HREE-enriched over LREE), positive Ce-anomalies and negative Eu-anomalies, high Th/U ratios (0.59-7.77).

(3) In discrimination diagrams based on the concentrations of several indicator elements (Yb, U, Y, Hf, etc.), the zircons fall into the fields of zircons from rocks of continental crust, mostly granitoids. Our results show the zircons to be derived from ancient continental crust and thus being genuine xenocrysts with respect to the host gabbro-diorite.

(4) During their residence within young oceanic crust, the zircons xenocrysts experienced the influence of a hightemperature hydrothermal fluid, which reduced the $\delta^{18} \mathrm{O}$ values of the zircons to $1.75 \% \mathrm{o}-3.15 \%$.

\section{ACKNOWLEDGMENTS}

The study was funded by the National Key R \& D Program of China (No. 2016YFE0203000) and the National Natural Science Foundation of China (No. 41673018). This study was also conducted under state contract (Institute of Precambrian Geology and Geochronology of Russian Academy of Sciences) (No. FMNU-2022-0005). Dmitriy I. Rezvukhin was supported by the state assignment project of IGM SB RAS. We thank Pavel Lvov for his help with U-Pb isotopic analyses, and Guoqiang Tang and Yu Liu for help with O isotopic analyses. Sergey Simakin and Evgeny Potapov assisted with measuring of zircon trace element compositions. Three anonymous reviewers provided valuable comments that improved the quality of the manuscript. The final publication is available at Springer via https://doi.org/10.1007/s12583-021-1422-2

Electronic Supplementary Material: Supplementary material (Table S1) is available in the online version of this article at https://doi.org/10.1007/s12583-021-1422-2. 
Open Access: This article is licensed under a Creative Commons Attribution 4.0 International License, which permits use, sharing, adaptation, distribution and reproduction in any medium or format, as long as you give appropriate credit to the original author(s) and the source, provide a link to the Creative Commons licence, and indicate if changes were made. The images or other third party material in this article are included in the article's Creative Commons licence, unless indicated otherwise in a credit line to the material. If material is not included in the article's Creative Commons licence and your intended use is not permitted by statutory regulation or exceeds the permitted use, you will need to obtain permission directly from the copyright holder. To view a copy of this licence, visit http:// creativecommons.org/licenses/by/4.0/.

\section{REFERENCES CITED}

Aranovich, L. Y., Zinger, T. F., Bortnikov, N. S., et al., 2013. Zircon in Gabbroids from the Axial Zone of the Mid-Atlantic Ridge, Markov Deep, $6^{\circ} \mathrm{N}$ : Correlation of Geochemical Features with Petrogenetic Processes. Petrology, 21(1): 1-15. https://doi.org/10.1134/ s0869591113010025

Ashwal, L. D., Wiedenbeck, M., Torsvik, T. H., 2017. Archaean Zircons in Miocene Oceanic Hotspot Rocks Establish Ancient Continental Crust beneath Mauritius. Nature Communications, 8: 14086. https://doi.org/ 10.1038/ncomms 14086

Balashov, Y. A., Skublov, S. G., 2011. Contrasting Geochemistry of Magmatic and Secondary Zircons. Geochemistry International, 49(6): 594-604. https://doi.org/10.1134/s0016702911040033

Ballard, J. R., Palin, M. J., Campbell, I. H., 2002. Relative Oxidation States of Magmas Inferred from $\mathrm{Ce}(\mathrm{IV}) / \mathrm{Ce}(\mathrm{III})$ in Zircon: Application to Porphyry Copper Deposits of Northern Chile. Contributions to Mineralogy and Petrology, 144(3): 347-364. https://doi. org/10.1007/ s00410-002-0402-5

Bau, M., Dulski, P., 1999. Comparing Yttrium and Rare Earths in Hydrothermal Fluids from the Mid-Atlantic Ridge: Implications for $\mathrm{Y}$ and REE Behaviour during Near-Vent Mixing and for the Y/Ho Ratio of Proterozoic Seawater. Chemical Geology, 155(1/2): 77-90. https:// doi.org/10.1016/s0009-2541(98)00142-9

Bea, F., Bortnikov, N., Montero, P., et al., 2020. Zircon Xenocryst Evidence for Crustal Recycling at the Mid-Atlantic Ridge. Lithos, 354/355: 105361. https://doi.org/10.1016/j.lithos.2019.105361

Belousova, E. A., Griffin, W. L., O’ Reilly, S. Y., 2006. Zircon Crystal Morphology, Trace Element Signatures and Hf Isotope Composition as a Tool for Petrogenetic Modelling: Examples from Eastern Australian Granitoids. Journal of Petrology, 47(2): 329-353. https://doi.org/ 10.1093/petrology/egi077

Belousova, E. A., Griffin, W. L., O’ Reilly, S. Y., et al., 2002. Igneous Zircon: Trace Element Composition as an Indicator of Source Rock Type. Contributions to Mineralogy and Petrology, 143(5): 602-622. https://doi.org/10.1007/s00410-002-0364-7

Belyatskii, B. V., Levskii, L., Trukhalev, A. I., et al., 1997. Precambrian Granite-Gneiss from the Mid-Atlantic Ridge $\left(26^{\circ} \mathrm{N}\right)$ : A U-Pb and SmNd Isotopic Study. Geochemistry International, 35(8): 770-773

Bindeman, I., 2008. Oxygen Isotopes in Mantle and Crustal Magmas as Revealed by Single Crystal Analysis. Reviews in Mineralogy and Geochemistry, 69(1): 445-478. https://doi.org/10.2138/rmg.2008.69.12

Black, L. P., Kamo, S. L., Allen, C. M., et al., 2004. Improved ${ }^{206} \mathrm{~Pb} /{ }^{238} \mathrm{U}$ Microprobe Geochronology by the Monitoring of a Trace-Element-
Related Matrix Effect; SHRIMP, ID-TIMS, ELA-ICP-MS and Oxygen Isotope Documentation for a Series of Zircon Standards. Chemical Geology, 205(1/2): 115-140. https://doi.org/10.1016/j.chemgeo. 2004.01 .003

Bortnikov, N. S., Sharkov, E. V., Bogatikov, O. A., et al., 2008. Finds of Young and Ancient Zircons in Gabbroids of the Markov Deep, MidAtlantic Ridge, $5^{\circ} 54^{\prime}-5^{\circ} 02.2^{\prime} \mathrm{N}$ (Results of SHRIMP-II U-Pb Dating): Implication for Deep Geodynamics of Modern Oceans. Doklady Earth Sciences, 421: 859-866. https://doi.org/10.1134/s1028334x08050334

Bortnikov, N. S., Silantyev, S. A., Bea, F., et al., 2019. U-Pb Dating, Oxygen and Hafnium Isotope Ratios of Zircon from Rocks of Oceanic Core Complexes at the Mid-Atlantic Ridge: Evidence for the Interaction of Contemporary and Ancient Crusts in the Spreading Center of the Ocean Floor. Doklady Earth Sciences, 489(2): 13961401. https://doi.org/10.1134/s1028334x19120109

Bouvier, A. S., Ushikubo, T., Kita, N. T., et al., 2012. Li Isotopes and Trace Elements as a Petrogenetic Tracer in Zircon: Insights from Archean TTGs and Sanukitoids. Contributions to Mineralogy and Petrology, 163(5): 745-768. https://doi.org/10.1007/s00410-011-0697-1

Bröcker, M., Löwen, K., Rodionov, N., 2014. Unraveling Protolith Ages of Meta-Gabbros from Samos and the Attic-Cycladic Crystalline Belt, Greece: Results of a U-Pb Zircon and Sr-Nd Whole Rock Study. Lithos, 198/199: 234-248. https://doi.org/10.1016/j.lithos.2014.03.029

Cheng, H., Zhou, H. Y., Yang, Q. H., et al., 2016. Jurassic Zircons from the Southwest Indian Ridge. Scientific Reports, 6: 26260. https://doi. org/ $10.1038 /$ srep26260

Corfu, F., Hanchar, J. M., Hoskin, P. W. O., et al., 2003. Atlas of Zircon Textures. Reviews in Mineralogy and Geochemistry, 53(1): 469-500. https://doi.org/10.2113/0530469

Dokukina, K. A., Kaulina, T. V., Konilov, A. N., et al., 2014. Archaean to Palaeoproterozoic High-Grade Evolution of the Belomorian Eclogite Province in the Gridino Area, Fennoscandian Shield: Geochronological Evidence. Gondwana Research, 25(2): 585-613. https://doi.org/10.1016/j.gr.2013.02.014

Douglass, J., Schilling, J. G., Fontignie, D., 1999. Plume-Ridge Interactions of the Discovery and Shona Mantle Plumes with the Southern MidAtlantic Ridge $\left(40^{\circ}-55^{\circ} \mathrm{S}\right)$. Journal of Geophysical Research: Solid Earth, 104(B2): 2941-2962. https://doi.org/10.1029/98jb02642

Eiler, J. M., 2001. Oxygen Isotope Variations of Basaltic Lavas and Upper Mantle Rocks. Reviews in Mineralogy and Geochemistry, 43(1): 319364. https://doi.org/10.2138/gsrmg.43.1.319

Fedotova, A. A., Bibikova, E. V., Simakin, S. G., 2008. Ion-Microprobe Zircon Geochemistry as an Indicator of Mineral Genesis during Geochronological Studies. Geochemistry International, 46(9): 912927. https://doi.org/10.1134/s001670290809005x

Finch, R. J., Hanchar, J. M., 2003. Structure and Chemistry of Zircon and Zircon-Group Minerals. Reviews in Mineralogy and Geochemistry, 53(1): 1-25. https://doi.org/10.2113/0530001

Fisher, R. L., Sclater, J. G., 1983. Tectonic Evolution of the Southwest Indian Ocean since the Mid-Cretaceous: Plate Motions and Stability of the Pole of Antarctica/Africa for at Least 80 Myr. Geophysical Journal International, 73(2): 553-576. https://doi.org/10.1111/j.1365-246x. 1983.tb03330.x

Frey, F. A., Weis, D., Borisova, A. Y., et al., 2002. Involvement of Continental Crust in the Formation of the Cretaceous Kerguelen Plateau: New Perspectives from ODP Leg 120 Sites. Journal of Petrology, 43(7): 1207-1239. https://doi.org/10.1093/petrology/ 43.7.1207 
Fu, B., Mernagh, T. P., Kita, N. T., et al., 2009. Distinguishing Magmatic Zircon from Hydrothermal Zircon: A Case Study from the Gidginbung High-Sulphidation Au-Ag- $(\mathrm{Cu})$ Deposit, SE Australia. Chemical Geology, 259(3/4): 131-142. https://doi.org/10.1016/j.chemgeo. 2008.10.035

Geisler, T., Schleicher, H., 2000. Improved U-Th-Total Pb Dating of Zircons by Electron Microprobe Using a Simple New Background Modeling Procedure and $\mathrm{Ca}$ as a Chemical Criterion of Fluid-Induced U-Th-Pb Discordance in Zircon. Chemical Geology, 163(1/2/3/4): 269-285. https://doi.org/10.1016/s0009-2541(99)00099-6

Georgen, J. E., Lin, J., Dick, H. J. B., 2001. Evidence from Gravity Anomalies for Interactions of the Marion and Bouvet Hotspots with the Southwest Indian Ridge: Effects of Transform Offsets. Earth and Planetary Science Letters, 187(3/4): 283-300. https://doi.org/10.1016/ s0012-821x(01)00293-x

Gregory, R. T., Taylor, H. P. Jr., 1981. An Oxygen Isotope Profile in a Section of Cretaceous Oceanic Crust, Samail Ophiolite, Oman: Evidence for $\delta^{18} \mathrm{O}$ Buffering of the Oceans by Deep $(>5 \mathrm{~km})$ SeawaterHydrothermal Circulation at Mid-Ocean Ridges. Journal of Geophysical Research: Solid Earth, 86(B4): 2737-2755. https://doi. org/10.1029/jb086ib04p02737

Grimes, C. B., John, B. E., Cheadle, M. J., et al., 2009. On the Occurrence, Trace Element Geochemistry, and Crystallization History of Zircon from in situ Ocean Lithosphere. Contributions to Mineralogy and Petrology, 158(6): 757-783. https://doi.org/10.1007/s00410-0090409-2

Grimes, C. B., John, B. E., Kelemen, P. B., et al., 2007. Trace Element Chemistry of Zircons from Oceanic Crust: A Method for Distinguishing Detrital Zircon Provenance. Geology, 35(7): 643-646. https://doi.org/10.1130/g23603a.1

Grimes, C. B., Ushikubo, T., John, B. E., et al., 2011. Uniformly MantleLike $\delta^{18} \mathrm{O}$ in Zircons from Oceanic Plagiogranites and Gabbros. Contributions to Mineralogy and Petrology, 161(1): 13-33. https://doi. org/10.1007/s00410-010-0519-x

Grimes, C. B., Wooden, J. L., Cheadle, M. J., et al., 2015. "Fingerprinting" Tectono-Magmatic Provenance Using Trace Elements in Igneous Zircon. Contributions to Mineralogy and Petrology, 170(5/6): 46. https: //doi.org/10.1007/s00410-015-1199-3

Hinton, R. W., Upton, B. G. J., 1991. The Chemistry of Zircon: Variations within and between Large Crystals from Syenite and Alkali Basalt Xenoliths. Geochimica et Cosmochimica Acta, 55(11): 3287-3302. https://doi.org/10.1016/0016-7037(91)90489-r

Hoskin, P. W. O., 2005. Trace-Element Composition of Hydrothermal Zircon and the Alteration of Hadean Zircon from the Jack Hills, Australia. Geochimica et Cosmochimica Acta, 69(3): 637-648. https:// doi.org/10.1016/j.gca.2004.07.006

Hoskin, P. W. O., Schaltegger, U., 2003. The Composition of Zircon and Igneous and Metamorphic Petrogenesis. Reviews in Mineralogy and Geochemistry, 53(1): 27-62. https://doi.org/10.2113/0530027

Jochum, K. P., Dingwell, D. B., Rocholl, A., et al., 2000. The Preparation and Preliminary Characterisation of Eight Geological MPI-DING Reference Glasses for in-situ Microanalysis. Geostandards and Geoanalytical Research, 24(1): 87-133. https://doi.org/10.1111/j.1751908x.2000.tb00590.x

Jochum, K. P., Stoll, B., Herwig, K., et al., 2006. MPI-DING Reference Glasses for in situ Microanalysis: New Reference Values for Element Concentrations and Isotope Ratios. Geochemistry, Geophysics, Geosystems, 7(2). https://doi.org/10.1029/2005gc001060
Kamenetsky, V. S., Maas, R., Sushchevskaya, N. M., et al., 2001. Remnants of Gondwanan Continental Lithosphere in Oceanic Upper Mantle: Evidence from the South Atlantic Ridge. Geology, 29(3): 243-246. https://doi.org/10.1130/0091-7613(2001)0290243: rogcli>2.0.co;2

Kirkland, C. L., Whitehouse, M. J., Slagstad, T., 2009. Fluid-Assisted Zircon and Monazite Growth within a Shear Zone: A Case Study from Finnmark, Arctic Norway. Contributions to Mineralogy and Petrology, 158(5): 637-657. https://doi.org/10.1007/s00410-009-0401-x

Korolev, N. M., Melnik, A. E., Li, X. H., et al., 2018. The Oxygen Isotope Composition of Mantle Eclogites as a Proxy of Their Origin and Evolution: A Review. Earth-Science Reviews, 185: 288-300. https:// doi.org/10.1016/j.earscirev.2018.06.007

Kostitsyn, Y. A., Belousova, E. A., Bortnikov, N. S., et al., 2009. Zircons in Gabbroids from the Axial Zone of the Mid-Atlantic Ridge: U-Pb Age and ${ }^{176} \mathrm{Hf} /{ }^{177} \mathrm{Hf}$ Ratio (Results of Investigations by the Laser Ablation Method). Doklady Earth Sciences, 429: 1305. https://doi. org/10.1134/ s1028334x09080145

Kostitsyn, Y. A., Belousova, E. A., Silant' ev, S. A., et al., 2015. Modern Problems of Geochemical and U-Pb Geochronological Studies of Zircon in Oceanic Rocks. Geochemistry International, 53(9): 759785. https://doi.org/10.1134/s0016702915090025

Kostitsyn, Y. A., Silantyev, S. A., Anosova, M. O., et al., 2018. Age of Plutonic Rocks from the Vema Fracture Zone (Central Atlantic) and Nature of Their Mantle Sources. Geochemistry International, 56(2): 89-110. https://doi.org/10.1134s0016702918020039

Kremenetskiy, A. A., Gromalova, N. A., Skolotnev, S. G., et al., 2018. Sources of Magmatic Rocks from the Deep-Sea Floor of the Arctic Ocean and the Central Atlantic: Evidence from Data on the U-Pb Age, Hf Isotopes, and REE Geochemistry of Zircons. Doklady Earth Sciences, 481(1): 852-856. https://doi.org/10.1134/s1028334x1807 0139

le Roux, P. J., le Roex, A. P., Schilling, J. G., et al., 2002. Mantle Heterogeneity beneath the Southern Mid-Atlantic Ridge: Trace Element Evidence for Contamination of Ambient Asthenospheric Mantle. Earth and Planetary Science Letters, 203(1): 479-498. https:// doi.org/10.1016/s0012-821x(02)00832-4

Leontev, V. I., Skublov, S. G., Shatova, N. V., et al., 2020. Zircon U-Pb Geochronology Recorded Late Cretaceous Fluid Activation in the Central Aldan Gold Ore District, Aldan Shield, Russia: First Data. Journal of Earth Science, 31(3): 481-491. https://doi.org/10.1007/ s12583-020-1304-z

Li, X. H., Long, W. G., Li, Q. L., et al., 2010. Penglai Zircon Megacrysts: A Potential New Working Reference Material for Microbeam Determination of Hf-O Isotopes and U-Pb Age. Geostandards and Geoanalytical Research, 34(2): 117-134. https://doi.org/10.1111/ j.1751-908x.2010.00036.x

Lin, J., Dick, H. J., Schouten, H., et al., 2001. Evidence for Off-Axis Volcanic Relicts of the Bouvet Hotspot and Its Interaction with the Southwest Indian Ridge. (2022-01-12). https://ui.adsabs.harvard.edu/ abs/2001AGUFM.T31D..10L/abstract

Lin, J., Georgen, J. E., Dick, H., 2003. Ridge-Hotspot Interactions at UltraSlow Spreading Conditions: Bouvet/Marion Hotspot and the SW Indian Ridge. InterRidge Symposium and Workshop: Ridge-Hotspot Interaction: Recent Progress and Prospects for Enhanced International Collaboration, September 8-10, 2003, Brest. 30

Ludwig, K. R., 2001. Squid 1.02: A User's Manual. Berkeley Geochronological Center Special Publication, Berkeley. 2: 19

Ludwig, K. R., 2003. Isoplot 3.00: A Geochronological Toolkit for 
Microsoft Excel. Berkeley Geochronology Center Special Publication, Berkeley. 4: 71

McDonough, W. F., Sun, S. S., 1995. The Composition of the Earth. Chemical Geology, 120(3/4): 223-253. https://doi. org/10.1016/00092541(94)00140-4

Michard, A., Albarède, F., 1986. The REE Content of some Hydrothermal Fluids. Chemical Geology, 55(1/2): 51-60. https://doi. org/10.1016/ 0009-2541(86)90127-0

Middlemost, E. A. K., 1994. Naming Materials in the Magma/Igneous Rock System. Earth-Science Reviews, 37(3/4): 215-224. https://doi. org/ 10.1016/0012-8252(94)90029-9

Norton, I. O., Sclater, J. G., 1979. A Model for the Evolution of the Indian Ocean and the Breakup of Gondwanaland. Journal of Geophysical Research: Solid Earth, 84(B12): 6803-6830. https://doi. org/10.1029/ jb084ib12p06803

Pilot, J., Werner, C. D., Haubrich, F., et al., 1998. Palaeozoic and Proterozoic Zircons from the Mid-Atlantic Ridge. Nature, 393(6686): 676-679. https://doi.org/10.1038/31452

Rocholl, A. B. E., Simon, K., Jochum, K. P., et al., 1997. Chemical Characterisation of NIST Silicate Glass Certified Reference Material SRM 610 by ICP-MS, TIMS, LIMS, SSMS, INAA, AAS and PIXE. Geostandards and Geoanalytical Research, 21(1): 101-114. https://doi. org/10.1111/j.1751-908x.1997.tb00537.x

Rodionov, N. V., Belyatsky, B. V., Antonov, A. V., et al., 2012. Comparative in-situ U-Th- $\mathrm{Pb}$ Geochronology and Trace Element Composition of Baddeleyite and Low-U Zircon from Carbonatites of the Palaeozoic Kovdor Alkaline-Ultramafic Complex, Kola Peninsula, Russia. Gondwana Research, 21(4): 728-744. https://doi.org/10.1016/j.gr. 2011.10.005

Rumyantseva, N. A., Vanshteyn, B. G., Skublov, S. G., 2021. Petrochemical Features of Tholeiites from the Shaka Ridge (South Atlantic). Journal of Mining Institute, 248: 223-231. https://doi.org/10.31897/pmi. 2021.2 .6

Sauter, D., Cannat, M., 2010. The Ultraslow Spreading Southwest Indian Ridge. In: Rona, P. A., Devey, C. W., Dyment, J., eds., Geophysical Monograph Series. American Geophysical Union, Washington D. C. 153-173. https://doi.org/10.1029/2008gm000843

Sharkov, E. V., Bortnikov, N. S., Bogatikov, O. A., et al., 2004. Mesozoic Zircon from Gabbronorites of the Axial Mid-Atlantic Ridge, $6^{\circ} \mathrm{N}$, Markov Deep. Doklady Earth Sciences, 397(5): 654-657

Shulyatin, O. G., Belyatsky, B. V., Kremenetsky, A. A., 2019. Geochemical and Geochronological Studies of Polychronic Zircons in Igneous Rocks from the Mid-Atlantic Ridge and Some Features of Its Structure. Regional Geology and Metallogeny, 77: 11-19 (in Russian)

Skolotnev, S. G., Bel' tenev, V. E., Lepekhina, E. N., et al., 2010. Younger and Older Zircons from Rocks of the Oceanic Lithosphere in the
Central Atlantic and Their Geotectonic Implications. Geotectonics, 44(6): 462-492. https://doi.org/10.1134/s0016852110060038

Tang, G. Q., Li, X. H., Li, Q. L., et al., 2015. Deciphering the Physical Mechanism of the Topography Effect for Oxygen Isotope Measurements Using a Cameca IMS-1280 SIMS. Journal of Analytical Atomic Spectrometry, 30(4): 950-956. https://doi.org/10.1039/ c4ja00458b

Torsvik, T. H., Amundsen, H., Hartz, E. H., et al., 2013. A Precambrian Microcontinent in the Indian Ocean. Nature Geoscience, 6(3): 223227. https://doi.org/10.1038/ngeo1736

Ushikubo, T., Kita, N. T., Cavosie, A. J., et al., 2008. Lithium in Jack Hills Zircons: Evidence for Extensive Weathering of Earth's Earliest Crust. Earth and Planetary Science Letters, 272(3/4): 666-676. https://doi. org/10.1016/j.eps1.2008.05.032

Valley, J. W., Kinny, P. D., Schulze, D. J., et al., 1998. Zircon Megacrysts from Kimberlite: Oxygen Isotope Variability among Mantle Melts. Contributions to Mineralogy and Petrology, 133(1/2): 1-11. https://doi. org/10.1007/s004100050432

Valley, J. W., Lackey, J. S., Cavosie, A. J., et al., 2005. 4.4 Billion Years of Crustal Maturation: Oxygen Isotope Ratios of Magmatic Zircon. Contributions to Mineralogy and Petrology, 150(6): 561-580. https:// doi.org/10.1007/s00410-005-0025-8

Watson, E. B., Wark, D. A., Thomas, J. B., 2006. Crystallization Thermometers for Zircon and Rutile. Contributions to Mineralogy and Petrology, 151(4): 413-433. https://doi.org/10.1007/s00410-0060068-5

Wiedenbeck, M., Allé, P., Corfu, F., et al., 1995. Three Natural Zircon Standards for U-Th-Pb, Lu-Hf, Trace Element and REE Analyses. Geostandards and Geoanalytical Research, 19(1): 1-23. https://doi. org/10.1111/j.1751-908x.1995.tb00147.x

Wiedenbeck, M., Hanchar, J. M., Peck, W. H., et al., 2004. Further Characterisation of the 91500 Zircon Crystal. Geostandards and Geoanalytical Research, 28(1): 9-39. https://doi.org/10.1111/j.1751908x.2004.tb01041.x

Williams, I. S., 1998. U-Th-Pb Geochronology by Ion Microprobe. Applications of Microanalytical Techniques to Understanding Mineralizing Processes. Society of Economic Geologists, 7: 1-35

Xu, H. J., Zhang, J. F., 2018. Zircon Geochronological Evidence for Participation of the North China Craton in the Protolith of Migmatite of the North Dabie Terrane. Journal of Earth Science, 29(1): 30-42. https://doi.org/10.1007/s12583-017-0805-x

Zhao, Y., Zheng, J. P., Xiong, Q., 2019. Zircon from Orogenic Peridotite: an Ideal Indicator for Mantle-Crust Interaction in Subduction Zones. Journal of Earth Science, 30(3): 666-678. https://doi.org/10.1007/ s12583-019-1220-2 